\title{
Hyperuricemia in Patients With Coronary Artery Disease and Its Association With Disease Severity
}

Jaskamal Padda $^{1}$, Khizer Khalid ${ }^{1}$, Abdulelah H. Almanie ${ }^{1}$, Hussam Al Hennawi ${ }^{1}$, Krutagni Adwait Mehta ${ }^{1}$, Ransirini Wijeratne Fernando ${ }^{1}$, Sandeep Padda ${ }^{1}$, Ayden Charlene Cooper ${ }^{1}$, Gutteridge Jean-Charles ${ }^{1,2}$

1. Internal Medicine, JC Medical Center, Orlando, USA 2. Internal Medicine, AdventHealth \& Orlando Health Hospital, Orlando, USA

Corresponding author: Sandeep Padda, sandeep.3@hotmail.com

\begin{abstract}
The biochemical background of coronary artery disease (CAD) has been intensively explored in the past several decades. Previous clinical investigations have demonstrated the association of non-traditional risk factors, such as hyperuricemia, with CAD. Studies have shown that increased serum uric acid (SUA) was associated with an increased risk of adverse cardiovascular (CV) outcomes in patients with CAD. While the exact pathophysiological mechanisms leading to increased risk are still unknown, it has been postulated that hyperuricemia leads to endothelial dysfunction, oxidative metabolism, and platelet adhesiveness and aggregation, leading to $\mathrm{CAD}$. Moreover, previous studies have shown that hyperuricemia is an independent risk factor for CAD. However, the correlation between high SUA levels and the severity of CAD remains unclear. The purpose of this review was to elucidate the association of hyperuricemia to CAD severity and to determine the effect of urate-lowering therapy (ULT) on CAD. A search of PubMed up to June 24, 2021, was carried out by the reviewers. From the findings, hyperuricemia stands as an independent risk factor for CAD, and CAD patients treated with ULT had improved CV outcomes and reduced mortality. Therefore, while SUA level is valuable in predicting an augmented risk of CAD and anticipating worse outcomes, ULT has promising cardioprotective effects.
\end{abstract}

Categories: Cardiology, Family/General Practice, Internal Medicine

Keywords: cad: coronary artery disease, uric acid, hyperuricemia, cardiovascular disease, colchicine

\section{Introduction And Background}

Hyperuricemia has been described to be associated with cardiovascular (CV) diseases, including hypertension, stroke, and coronary artery disease (CAD). However, the mechanism of how serum uric acid (SUA) is associated with CAD has not been elucidated [1]. The exact role of SUA as an independently standing coronary heart disease risk factor is still controversial [2].

Review began 07/30/2021 Review ended 08/03/2021 Published 08/13/2021

\section{() Copyright 2021}

Padda et al. This is an open access article distributed under the terms of the Creative Commons Attribution License CC-BY 4.0., which permits unrestricted use, distribution, and reproduction in any medium, provided the original author and source are credited.
Moreover, since other comorbidities frequently exist with CAD, it is considered complex to differentiate the SUA function in this instance. CAD is considered to be the leading cause of death in the elderly population, with an incidence rate greater than $80 \%$ occurring in patients older than 65 years [1]. Pathophysiological mechanisms associating hyperuricemia with CAD have been established, with SUA being a stimulant to oxidative stress, inducing the production of oxygen free radicals and adhesion of platelets. These processes result in inflammatory reactions and dysfunction of the endothelium, which may explain the correlation between hyperuricemia and $\mathrm{CAD}[3]$.

Zuo et al. have concluded that hyperuricemia creates a potential risk for CAD and its associated mortality [3]. Although it has been stated that there are both safe and effective measures that can be used to lower SUA levels and therefore reduce cardiac disease, these still have to be explored further. In highlighting the cruciality of the SUA levels in association to CAD, Kim, et al. have noticed that the risk of death due to CAD is elevated by $12 \%$ for each $1 \mathrm{mg} / \mathrm{dl}$ increase of SUA [2].

\section{Review}

\section{Coronary artery disease}

$\mathrm{CAD}$ is a pathologic condition that occurs when there is inadequacy in both blood supply and oxygen to the myocardial tissue. This condition results from luminal plaque formation in the coronary arteries, leading to blood flow hindrance, further leading to arterial occlusion. CAD has been the leading cause of mortality, both worldwide and in the United States. Moreover, it reached its peak of incidence in the 1960s and remained to be the ultimate leading cause of mortality [4]. In the United States, 16.8 million are affected by CAD [5]. Furthermore, it accounts for almost 610,000 deaths each year in the United States [6].

The first manifestation of CAD is chronic stable angina, which occurs in $50 \%$ of the patients. This phenomenon is a manifestation of an arterial obstruction of at least one large epicardial artery. Reduction of the associated symptoms and ischemia in order to avoid myocardial infarction (MI) and consequent death is 
the highlight of CAD management [5].

Possible risk factors for CAD are further classified into modifiable and non-modifiable risk factors. The modifiable factors include hypertension, hyperlipidemia, obesity, diabetes mellitus, and smoking. On the other hand, non-modifiable risk factors include gender, ethnicity, family history, and age of the patient with increased prevalence in patients greater than 35 years old in all genders [6].

\section{Hyperuricemia}

Hyperuricemia is defined as extracellular fluid supersaturation with abnormally elevated levels of uric acid, which can be caused by different pathways such as genetic disorders, overproduction of uric acid, and decreased renal excretion [7]. The most common cause of hyperuricemia is renal underexcretion and this type of hyperuricemia is considered primary or idiopathic [7]. The cut-off serum level of hyperuricemia is > $7 \mathrm{mg} / \mathrm{dL}$, which can be precipitated by a diversity of risk factors, for instance, excessive consumption of a purine-rich diet, chemotherapy, and genetic disorders [8]. In humans, purine metabolism through the process of oxidation will yield in the production of uric acid [9]. Xanthine oxidoreductase is considered the catalyst enzyme participating in the process of converting hypoxanthine to xanthine and then further to uric acid [8]. Regardless of the evidence-based correlation between hyperuricemia and various types of disorders, for example, $\mathrm{CAD}$, heart failure, and chronic kidney disease, there are no obvious guidelines regarding the management of asymptomatic hyperuricemia [10]. Gout is a metabolic disorder that is characterized by the deposition of monosodium urate crystals in joint spaces, resulting in acute or recurrent inflammatory arthritis [11]. Since the correlation between elevated SUA levels and gout has been established, the symptomatology of hyperuricemia as an abnormal finding can range from asymptomatic to intense arthritis [11]. In cases where gout is left untreated, it can result in a chronic course of increased flare-ups, development of anatomical joint damage, and tophi [12]. The treatment of gout aims at reducing the levels of SUA. Elevated SUA can be caused and influenced by various factors like aging, dietary factors, and lifestyle [12]. The saturation point of the SUA level can be attributed as $6.8 \mathrm{mg} / \mathrm{dL}$ [12]. As a means of therapeutic approach, the treatment and prevention of gouty arthritis is implemented via pharmacologic intervention. Patients should receive urate-lowering therapy (ULT), with the goal of SUA level <6.0 mg/dL [12].

\section{Association between hyperuricemia and CAD}

Hyperuricemia has been found in $\mathrm{CAD}$, which is confirmed by angiography in the majority of population data, which is independent of other CV risk factors that are considered confounding. Hyperuricemia showed an independent trend in the severity of CAD. Gender variation in levels of uricemia was not found [13].

Some studies, including the Framingham Heart Study and the Atherosclerosis Risk in Communities (ARIC) study, have shown no association between uric acid and CAD [14-15]. However, numerous recent papers have suggested some association. Hiyamuta et al. did a case-control study on 1029 patients ( $87 \%$ male) who were undergoing coronary angiography. They divided them into four groups according to arteriographic findings [16]. Uric acid was not found to have an independent association with CAD or its severity. A few other studies like Kotake and colleagues, Tuttle and colleagues, etc. also found a linear relationship of SUA levels with CAD [17-18].

Fang and colleagues conducted a cross-sectional follow-up study, which has a representative sample of the United States adult population and has shown an increased level of association of increasing uric acid levels with CAD. Hazard ratios for men and women were determined after the adjustment of risk factors such as age, body mass index, cholesterol levels, smoking status, etc. [19-20]. High levels of SUA have been found as a strong risk factor for adverse outcomes and mortality in severe CAD (with > 70\% stenosis in coronary angiography) [21].

The study was done in Framingham, Massachusetts to examine uric acid serum levels in relation to death from all-cause, CAD, and incidence of CAD. A total of 117,376 person-years were examined to note 617 attributed to CAD, 1460 deaths from all causes, and $429 \mathrm{CV}$ deaths. The study did not find a causal role of SUA in CAD development, death from all causes, or death from cardiovascular diseases [15].

Hyperuricemia has not only been found to have an independent association with the development of CAD, but there is also complex interrelations with many other independent CV risk factors such as diabetes, obesity, metabolic syndrome, and chronic kidney disease [13]. This makes it hard to confirm independent studies to investigate a firm, independent association of uric acid levels with CAD. Although the association of hyperuricemia with CAD has been found in many studies, some studies have also shown severity association with CAD [13].

A multivariate study on 771 participants with $37 \%$ participants having high uric acid levels (defined as $>6$ $\mathrm{mg} / \mathrm{dl}$ in females and $>7$ in males) showed high uric acid levels as an independent risk factor in CAD severity [12]. Incidence of CAD is rare but rising in the age group less than 35 years. This study has shown hyperuricemia as an independent risk factor for acute coronary syndrome in the 18-35 age group [22].

The prognostic value stays unclear with CAD with heavy atherosclerotic burden in all three vessels. A cohort 


\section{Cureus}

study of 8529 patients was conducted to determine the all-cause death as an endpoint, propensity score matching was done to compare two cohort groups. Hyperuricemia was present in $14.2 \%$ of total patients. At baseline hyperuricemia, patients had more comorbidities. During 7.5 years of median follow-up,

hyperuricemia patients had been associated with significantly more deaths $(39.11 \%$ more death, $\mathrm{p}<0.001)$ compared with normouricemic patients [23]. Hyperuricemia was associated with a higher risk of mortality in a multivariate analysis (1.3 hazard ratio [HR] with 1.15 to $1.5395 \%$ confidence interval [CI], p<0.001). Also, similar results were found in propensity score matching ( $1.3 \mathrm{HR}, 1.11$ to $1.6195 \% \mathrm{CI}, \mathrm{p}<0.003)$. This association was found to be consistent in different subgroups except between age subgroups. This study also found a statistically significant association of hyperuricemia with CAD mortality [23]. Such disparity in study results may be due to the differences between genetic background and lifestyle, which affects uric acid levels. Uric acid level variability can also be due to various study populations and differences in sample size [24-25]. Table 1 discusses the association between hyperuricemia and CAD [15-18,22-23]. 


\section{Cureus}

\begin{tabular}{|c|c|c|c|c|c|c|}
\hline $\begin{array}{l}\text { Referenced } \\
\text { Trial }\end{array}$ & Sample Size & $\begin{array}{l}\text { Study } \\
\text { Participants }\end{array}$ & $\begin{array}{l}\text { Mean } \\
\text { Uric } \\
\text { Acid } \\
\text { Levels }\end{array}$ & Primary Outcomes & Objective & Conclusion \\
\hline $\begin{array}{l}\text { The } \\
\text { Framingham } \\
\text { Heart Study } \\
\text { (1999) } \\
\text { Massachusetts } \\
\text { [15] }\end{array}$ & 6763 & $\begin{array}{l}\text { Mean age of } 47 \\
\text { years old; } 3075 \\
\text { men, } 3688 \\
\text { women }\end{array}$ & $\begin{array}{l}\text { Men } \\
379 \\
\text { umol/L } \\
\pm 76 ; \\
\text { women } \\
285 \\
\text { umol/L } \\
\pm 69\end{array}$ & $\begin{array}{l}617 \text { coronary heart } \\
\text { disease events; } 429 \mathrm{CV} \\
\text { disease deaths; } 1460 \\
\text { deaths from all causes }\end{array}$ & $\begin{array}{l}\text { To examine the relation } \\
\text { of SUA level to incident } \\
\text { coronary heart disease, } \\
\text { death from CV disease, } \\
\text { and death from all } \\
\text { causes }\end{array}$ & $\begin{array}{l}\text { Uric acid does not have a } \\
\text { causal role in the } \\
\text { development of coronary } \\
\text { heart disease, death from } \\
\mathrm{CV} \text { disease, or death from } \\
\text { all causes }\end{array}$ \\
\hline $\begin{array}{l}\text { Hiyamuta K, et } \\
\text { al. (1990) } \\
\text { Japan [16] }\end{array}$ & $\begin{array}{l}1029 ; 644 \\
\text { patients with } \\
\text { previous Ml; } \\
385 \text { patients } \\
\text { with angina } \\
\text { pectoris }\end{array}$ & $\begin{array}{l}892 \text { men and } \\
137 \text { women }\end{array}$ & $\begin{array}{l}5.91 \\
\mathrm{mg} / \mathrm{dl} \\
\pm 1.54\end{array}$ & $\begin{array}{l}\text { SUA and smoking are } \\
\text { considered to be risk } \\
\text { factors for patients }\end{array}$ & $\begin{array}{l}\text { To analyze the } \\
\text { relationship between } \\
\text { coronary risk factors } \\
\text { and arteriographic } \\
\text { features of coronary } \\
\text { atherosclerosis }\end{array}$ & $\begin{array}{l}\text { Smoking and } \\
\text { hyperuricemia are strongly } \\
\text { correlated with all types of } \\
\text { coronary atherosclerosis }\end{array}$ \\
\hline $\begin{array}{l}\text { Kotake } \mathrm{H} \text {, et } \\
\text { al. (1992) [17] }\end{array}$ & 97 & $\begin{array}{l}40 \\
\text { postmenopausal } \\
\text { women, } 57 \text { men }\end{array}$ & N/A & $\begin{array}{l}\text { The mean value of SUA } \\
\text { increased as the number } \\
\text { of stenosed coronary } \\
\text { arteries increased } \\
\text { (greater or equal to } 50 \% \\
\text { stenosis) }\end{array}$ & $\begin{array}{l}\text { Relation between SUA } \\
\text { and angiographically } \\
\text { defined CAD in } \\
\text { postmenopausal women }\end{array}$ & $\begin{array}{l}\text { Elevated SUA levels } \\
\text { suggest the prevalence of } \\
\text { severe coronary artery } \\
\text { stenosis in } \\
\text { postmenopausal women }\end{array}$ \\
\hline $\begin{array}{l}\text { Tuttle KR, et } \\
\text { al. (2001) [18] }\end{array}$ & 277 & $\begin{array}{l}82 \text { women, } 195 \\
\text { men }\end{array}$ & $\begin{array}{l}5.4 \\
\mathrm{mg} / \mathrm{dL} \\
\text { for } \\
\text { women; } \\
6.3 \\
\mathrm{mg} / \mathrm{dL} \\
\text { for } \mathrm{men}\end{array}$ & $\begin{array}{l}\text { Linear elevation of SUA } \\
\text { in women; no change in } \\
\text { men }\end{array}$ & $\begin{array}{l}\text { To determine gender } \\
\text { differences in the risk } \\
\text { factors for CAD }\end{array}$ & $\begin{array}{l}\text { SUA is linearly related to } \\
\text { CAD severity in women, } \\
\text { not in men }\end{array}$ \\
\hline $\begin{array}{l}\text { Lv S, et al } \\
\text { (2019) [22] }\end{array}$ & 771 & $\begin{array}{l}\text { Mean age of } \\
31.6\end{array}$ & $\begin{array}{l}7.0 \\
\mathrm{mg} / \mathrm{dL} \\
\text { in men; } \\
6.0 \\
\mathrm{mg} / \mathrm{dL} \\
\text { in } \\
\text { women }\end{array}$ & $\begin{array}{l}\text { Gensini score identified } \\
\text { hyperuricemia to be an } \\
\text { independent risk factor } \\
\text { for CAD severity }\end{array}$ & $\begin{array}{l}\text { Assess the relationship } \\
\text { between hyperuricemia } \\
\text { and CAD severity }\end{array}$ & $\begin{array}{l}\text { Hyperuricemia was shown } \\
\text { to be an independent risk } \\
\text { factor for CAD severity in } \\
\text { young adults with ACS }\end{array}$ \\
\hline $\begin{array}{l}\text { Zhang C, et al. } \\
\text { (2018) China } \\
\text { [23] }\end{array}$ & 8529 & $\begin{array}{l}1749 \text { female, } \\
6780 \text { males }\end{array}$ & $\begin{array}{l}322 \\
\text { umol/L } \\
\text { in men; } \\
281.1 \\
\text { umol/L } \\
\text { in } \\
\text { women }\end{array}$ & $\begin{array}{l}\text { Hyperuricemia is } \\
\text { associated with an } \\
\text { increased risk of } \\
\text { mortality }\end{array}$ & $\begin{array}{l}\text { To evaluate the } \\
\text { prognostic value of } \\
\text { hyperuricemia in } \\
\text { patients with severe } \\
\text { CAD }\end{array}$ & $\begin{array}{l}\text { Individual increments in } \\
\text { SUA have been shown to } \\
\text { increase mortality risk in } \\
\text { patients with CAD }\end{array}$ \\
\hline
\end{tabular}

\section{TABLE 1: Association between hyperuricemia and CAD}

N/A - Not Available, CV - Cardiovascular, SUA - Serum Uric Acid, CAD - Coronary Artery Disease, ACS - Acute Coronary Syndrome

\section{Effect of anti-gout medications on CAD}

Current evidence illustrates the negative association of hyperuricemia and gout, which were shown to be independently associated with an elevated risk of heart diseases, including CAD, congestive heart failure, and fatal CV events [26]. In fact, known active gout patients who present with acute MI were shown to have worse survival outcomes in comparison to patients on gout treatment [27]. Moreover, the URic acid Right for heArt Health Study Group (URRAH) proved the independent link between SUA and severe cases of MI [28]. Of note, not all ULTs have been shown to improve CV outcomes, however, colchicine, a well-known gout medication, has shown a long-term reduction in fatal CV events in patients following recent MI and known 
stable ischemic heart disease patients.

The Colchicine Cardiovascular Outcomes Trial (COLCOT) demonstrated a 1.6\% absolute mortality reduction from CV causes, resuscitated cardiac arrest, recurrent MI in patients when treated with low-dose colchicine ( $0.5 \mathrm{mg}$ once daily) within 30 days of MI (Mean of 13.5 days after MI) compared with the placebo group (HR $0.77,95 \% \mathrm{CI} 0.61-0.96 ; p=0.02$ ) [29]. At a cellular level, in vitro application of colchicine was shown to inhibit platelet activity; reflecting decreased rates of in-stent stenosis and stabilization of coronary plaques following acute coronary syndrome in vivo [30]. Notably, a smaller infarct size (18.3 vs. $23.2 \mathrm{~mL} / 1.73 \mathrm{~m} 2 \mathrm{in}$ placebo; $p=0.019$ ) was demonstrated following the use of colchicine in ST-elevation MI within $12 \mathrm{~h}$ of the presentation along with standard percutaneous coronary intervention [31]. Additionally, two retrospective studies demonstrated a significant reduction of CV events in patients with gout managed with colchicine compared to people who were not on treatment [32-33]. Emerging evidence is advocating the costeffectiveness and safety profile of colchicine use among coronary vascular disease patients and larger trials with longer follow-up intervals are warranted in certain patient subgroups to emphasize associated benefits of colchicine therapy as add-on therapy or for secondary prevention of CV events.

Similar to colchicine, the ULT allopurinol has varying CV effects. According to a randomized control trial, allopurinol demonstrated increased exercise capacity, time to ST depression, and time to symptom onset (chest pain) in 65 patients with CAD [34]. Cardioprotective effects of allopurinol were also postulated in larger population-based and different case-control studies. In particular, de Abajo et al. brought to light possible protective effects of allopurinol following longer duration and higher dosage of treatment $>300 \mathrm{mg}$ compared with < $300 \mathrm{mg}$ ) [35]. Similarly, an observational study suggested protective effects of allopurinol for MI in elderly people supporting earlier Medicare claims [36]. Allopurinol benefits are not only limited to CAD; the possible blood-pressure reduction was also evident. Compared to placebo/no treatment, allopurinol $\leqslant 300 \mathrm{mg}$ daily was associated with insignificant reduction of major adverse cardiovascular events (MACE) and mortality, however, reduced risks of hypertension (Odds Ratio (OR) 0.54, 95\% CI 0.370.80 ) and total events (OR 0.60, 95\% CI 0.44-0.82) were observed [37]. Xanthine oxidase (XO) inhibition was also shown to enhance endothelial function and subsequent vasodilation and larger blood flow in patients with HF achieved by allopurinol in normouricemia and hyperuricemia patients suggesting a crucial effect of oxidative stress inhibition in such cohort [38].

Febuxostat, another XO inhibitor, demonstrated questionable cardioprotective effects. In fact, patients treated with febuxostat for gout reported a greater incidence of CV events compared to allopurinol treatment, although results were not statistically significant according to early trials [39-42]. The CARES trial, which was mandated by the United States Food and Drug Administration (USFDA), compared gout treatment with febuxostat or allopurinol for a median of 32 months. Although results have shown no significant difference in terms of the primary endpoint of composites, including CV death, non-fatal MI, non-fatal stroke, and unstable angina requiring revascularization. Nevertheless, the febuxostat group demonstrated significant CV mortality compared to allopurinol (HR 1.34, CI 95\% 1.03-1.73) [43]. For this reason, the USFDA announced a black box warning for the use of febuxostat in patients with gout who showed no response to maximum allopurinol therapy [44].

\section{Conclusions}

As the worldwide clinical and financial burden of CAD is rapidly rising, we have attempted to analyze the evidence suggesting a correlation between hyperuricemia and CAD. Because of the effects of SUA on atherogenesis, we hypothesized high levels of SUA were associated with the severity of CAD. Our findings suggested that high levels of SUA were significantly associated with the severity of CAD, apart from two studies that did not show a correlation. Whether the lack of correlation in those studies was due to confounding was unclear. Our findings also suggested that ULT (colchicine and allopurinol) was associated with cardioprotective effects and improved CV outcomes.

In addition to the evaluation of conventional risk factors in daily clinical practice, measurement of the SUA level might be an important, simple, and cost-effective vascular risk marker, which is routinely measured in clinical practice that can provide significant prognostic benefits in terms of global CV risk and management of patients; further, high levels of SUA levels may become surrogate markers of CAD severity. Moreover, ULT can gain recognition in the management of $\mathrm{CAD}$ in the future.

\section{Additional Information}

\section{Disclosures}

Conflicts of interest: In compliance with the ICMJE uniform disclosure form, all authors declare the following: Payment/services info: All authors have declared that no financial support was received from any organization for the submitted work. Financial relationships: All authors have declared that they have no financial relationships at present or within the previous three years with any organizations that might have an interest in the submitted work. Other relationships: All authors have declared that there are no other relationships or activities that could appear to have influenced the submitted work. 


\section{References}

1. Wu J, Lei G, Wang X, et al.: Asymptomatic hyperuricemia and coronary artery disease in elderly patients without comorbidities. Oncotarget. 2017, 8:80688-99. 10.18632/oncotarget.21079

2. Kim SY, Guevara JP, Kim KM, Choi HK, Heitjan DF, Albert DA: Hyperuricemia and coronary heart disease: a systematic review and meta-analysis. Arthritis Care Res (Hoboken). 2010, 62:170-80. 10.1002/acr.20065

3. Zuo T, Liu X, Jiang L, Mao S, Yin X, Guo L: Hyperuricemia and coronary heart disease mortality: a metaanalysis of prospective cohort studies. BMC Cardiovasc Disord. 2016, 16:207. 10.1186/s12872-016-0379-z

4. Shahjehan RD, Bhutta BS: Coronary Artery Disease. StatPearls [Internet], Treasure Island (FL): StatPearls Publishing; 2021.

5. Cassar A, Holmes DR Jr, Rihal CS, Gersh BJ: Chronic coronary artery disease: diagnosis and management. Mayo Clin Proc. 2009, 84:1130-46. 10.4065/mcp.2009.0391

6. Brown JC, Gerhardt TE, Kwon E: Risk Factors For Coronary Artery Disease. StatPearls [Internet], Treasure Island (FL): StatPearls Publishing; 2021.

7. Yamauchi T, Ueda T: Primary hyperuricemia due to decreased renal uric acid excretion [Article in Japanese] . Nihon Rinsho. 2008, 66:679-81.

8. Yamamoto T: Definition and classification of hyperuricemia [Article in Japanese] . Nihon Rinsho. 2008, 66:636-40.

9. Chen C, Lü JM, Yao Q: Hyperuricemia-related diseases and xanthine oxidoreductase (XOR) Inhibitors: an overview. Med Sci Monit. 2016, 22:2501-12. 10.12659/msm.899852

10. Skoczyńska M, Chowaniec M, Szymczak A, Langner-Hetmańczuk A, Maciążek-Chyra B, Wiland P: Pathophysiology of hyperuricemia and its clinical significance - a narrative review . Reumatologia. 2020, 58:312-23. 10.5114/reum.2020.100140

11. Chilappa CS, Aronow WS, Shapiro D, Sperber K, Patel U, Ash JY: Gout and hyperuricemia. Compr Ther. 2010, 36:3-13.

12. Ruoff G, Edwards NL: Overview of serum uric acid treatment targets in gout: why less than $6 \mathrm{mg} / \mathrm{dL}$ ? . Postgrad Med. 2016, 128:706-15. 10.1080/00325481.2016.1221732

13. Goodarzynejad H, Anvari MS, Boroumand MA, Karimi A, Abbasi SH, Davoodi G: Hyperuricemia and the presence and severity of coronary artery disease. Lab Med. 2010, 41:40-5. 10.1309/LMKDB9PBKZGUS20T

14. Alderman M, Aiyer KJ: Uric acid: role in cardiovascular disease and effects of losartan . Curr Med Res Opin. 2004, 20:369-79. 10.1185/030079904125002982

15. Culleton BF, Larson MG, Kannel WB, Levy D: Serum uric acid and risk for cardiovascular disease and death: the Framingham Heart Study. Ann Intern Med. 1999, 131:7-13. 10.7326/0003-4819-131-1-199907060-00003

16. Hiyamuta K, Toshima H, Koga Y, et al.: Relationship between coronary risk factor and arteriographic feature of coronary atherosclerosis : 53th Annual Scientific Session of the Japanese Circulation Society. Jpn Circ J. 1990, 54:442-7. 10.1253/jcj.54.442

17. Kotake H, Sawada Y, Hoshio A, et al.: Relation between serum uric acid and angiographically defined coronary artery disease in postmenopausal women. J Med. 1992, 23:409-15.

18. Tuttle KR, Short RA, Johnson RJ: Sex differences in uric acid and risk factors for coronary artery disease . Am J Cardiol. 2001, 87:1411-1414. 10.1016/s0002-9149(01)01566-1

19. Fang J, Alderman MH: Serum uric acid and cardiovascular mortality. The NHANES I epidemiologic followup study, 1971-1992. JAMA. 2000, 283:2404-10. 10.1001/jama.283.18.2404

20. Baker JF, Krishnan E, Chen L, Schumacher HR: Serum uric acid and cardiovascular disease: recent developments, and where do they leave us?. Am J Med. 2005, 118:816-26. 10.1016/j.amjmed.2005.03.043

21. Madsen TE, Muhlestein JB, Carlquist JF, et al.: Serum uric acid independently predicts mortality in patients with significant, angiographically defined coronary disease. Am J Nephrol. 2005, 25:45-9. $10.1159 / 000084085$

22. Lv S, Liu W, Zhou Y, et al.: Hyperuricemia and severity of coronary artery disease: an observational study in adults 35 years of age and younger with acute coronary syndrome. Cardiol J. 2019, 26:275-82. 10.5603/CJ.a2018.0022

23. Zhang C, Jiang L, Xu L, et al.: Implications of hyperuricemia in severe coronary artery disease . Am J Cardiol. 2019, 123:558-64. 10.1016/j.amjcard.2018.11.027

24. Alderman MH: Uric acid and cardiovascular risk. Curr Opin Pharmacol. 2002, 2:126-30. 10.1016/s14714892(02)00143-1

25. Johnson RJ, Kang DH, Feig D, et al.: Is there a pathogenetic role for uric acid in hypertension and cardiovascular and renal disease?. Hypertension. 2003, 41:1183-90. 10.1161/01.HYP.0000069700.62727.C5

26. Dalbeth N, Merriman TR, Stamp LK: Gout. Lancet. 2016, 388:2039-52. 10.1016/S0140-6736(16)00346-9

27. Krishnan E, Pandya BJ, Lingala B, Hariri A, Dabbous O: Hyperuricemia and untreated gout are poor prognostic markers among those with a recent acute myocardial infarction. Arthritis Res Ther. 2012, 14:R10. 10.1186/ar3684

28. Casiglia E, Tikhonoff V, Virdis A, et al.: Serum uric acid and fatal myocardial infarction: detection of prognostic cut-off values: the URRAH (Uric Acid Right for Heart Health) study. J Hypertens. 2020, 38:412-9. 10.1097/HJH.0000000000002287

29. Tardif JC, Kouz S, Waters DD, et al.: Efficacy and safety of low-dose colchicine after myocardial infarction. N Engl J Med. 2019, 381:2497-505. 10.1056/NEJMoa1912388

30. Deftereos S, Giannopoulos G, Raisakis K, et al.: Colchicine treatment for the prevention of bare-metal stent restenosis in diabetic patients. J Am Coll Cardiol. 2013, 61:1679-85. 10.1016/j.jacc.2013.01.055

31. Deftereos S, Giannopoulos G, Angelidis C, et al.: Anti-inflammatory treatment with colchicine in acute myocardial infarction. A pilot study. Circulation. 2015, 132:1395-403. 10.1161/CIRCULATIONAHA.115.017611

32. Solomon DH, Liu CC, Kuo IH, Zak A, Kim SC: Effects of colchicine on risk of cardiovascular events and mortality among patients with gout: a cohort study using electronic medical records linked with Medicare claims. Ann Rheum Dis. 2016, 75:1674-9. 10.1136/annrheumdis-2015-207984

33. Crittenden DB, Lehmann RA, Schneck L, et al.: Colchicine use is associated with decreased prevalence of 
myocardial infarction in patients with gout. J Rheumatol. 2012, 39:1458-64. 10.3899/jrheum.111533

34. Grunfeld C, Feingold KR: The metabolic effects of tumor necrosis factor and other cytokines . Biotherapy. 1991, 3:143-58. 10.1007/BF02172087

35. de Abajo FJ, Gil MJ, Rodríguez A, García-Poza P, Álvarez A, Bryant V, García-Rodríguez LA: Allopurinol use and risk of non-fatal acute myocardial infarction. Heart. 2015, 101:679-85. 10.1136/heartjnl-2014-306670

36. Singh JA, Yu S: Allopurinol reduces the risk of myocardial infarction (MI) in the elderly: a study of Medicare claims. Arthritis Res Ther. 2016, 18:209. 10.1186/s13075-016-1111-1

37. Bredemeier M, Lopes LM, Eisenreich MA, et al.: Xanthine oxidase inhibitors for prevention of cardiovascular events: a systematic review and meta-analysis of randomized controlled trials. BMC Cardiovasc Disord. 2018, 18:24. 10.1186/s12872-018-0757-9

38. Doehner W, Schoene N, Rauchhaus M, et al.: Effects of xanthine oxidase inhibition with allopurinol on endothelial function and peripheral blood flow in hyperuricemic patients with chronic heart failure. Results from 2 placebo-controlled studies. Circulation. 2002, 105:2619-24. 10.1161/01.cir.0000017502.58595.ed

39. Becker MA, Schumacher HR Jr, Wortmann RL, et al.: Febuxostat, a novel nonpurine selective inhibitor of xanthine oxidase: a twenty-eight-day, multicenter, phase II, randomized, double-blind, placebo-controlled, dose-response clinical trial examining safety and efficacy in patients with gout. Arthritis Rheum. 2005, 52:916-23. 10.1002/art.20935

40. Becker MA, Schumacher HR, MacDonald PA, Lloyd E, Lademacher C: Clinical efficacy and safety of successful longterm urate lowering with febuxostat or allopurinol in subjects with gout. J Rheumatol. 2009, 36:1273-82. 10.3899/jrheum.080814

41. Schumacher HR Jr, Becker MA, Wortmann RL, et al.: Effects of febuxostat versus allopurinol and placebo in reducing serum urate in subjects with hyperuricemia and gout: a 28-week, phase III, randomized, doubleblind, parallel-group trial. Arthritis Rheum. 2008, 59:1540-8. 10.1002/art.24209

42. Schumacher HR Jr, Becker MA, Lloyd E, MacDonald PA, Lademacher C: Febuxostat in the treatment of gout: 5-yr findings of the FOCUS efficacy and safety study. Rheumatology (Oxford). 2009, 48:188-94. 10.1093/rheumatology/ken457

43. White WB, Saag KG, Becker MA, et al.: Cardiovascular safety of febuxostat or allopurinol in patients with gout. N Engl J Med. 2018, 378:1200-10. 10.1056/NEJMoa1710895

44. Abeles AM, Pillinger MH: Febuxostat and the black box blues . ACR Open Rheumatol. 2019, 1:343-4. 10.1002/acr2.11047 